\title{
Azerbaijan libraries in the structure of the global network of scientific knowledge distribution: challenges of the post-soviet era
}

\author{
N.Kh. Babakhanova \\ Azerbaijan National Academy of Sciences \\ Azerbaijan \\ e-mail:nbabakhanova@gmail.com \\ Javid A. Jafarov \\ Azerbaijan National Academy of Sciences \\ Azerbaijan \\ e-mail: jafarov@scientia.az
}

Abstract. Azerbaijan as almost all other post-soviet countries in the early $90^{\text {th }}$ appeared cut-off from the global network of scientific knowledge distribution. Government of Azerbaijan in cooperation with local scientific community developed a State ActionPlan in order to change this situation. In the present article, the authors examined activities of the Central Scientific Library of Azerbaijan National Academy of Sciences, as one of the main components of such plan, focusing on the key problems faced by the library, especially in terms of international relations, and solutions developed, which

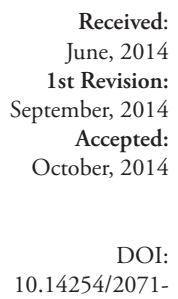

Received: June, 2014 1st Revision: September, 2014

Accepted: October, 2014

DOI: $10.14254 / 2071-$ $8330.2014 / 7-3 / 16$ allowed Azerbaijan to become a part of the global network of scientific knowledge distribution.

Keywords: Azerbaijani libraries, foreign book exchange, 1990-2000s

JEL Classification: Z11

\section{INTRODUCTION}

The successful reforms, creative works carried out in Azerbaijan lately, as well as progresses in the economy and the development of non-oil sector have yielded positive results, substantial measures being taken in respect of the socio-economic development of the regions and the improvement of the social standing of the population. One of the principal tendencies of the public policy was the adoption of a number of important decisions in regard to rendering a successive care to science, education and culture, keeping scientific and technical potential, training highly skilled personnel in the field of science and education and providing their care, and the rise of the scientists' authority in the society (Azerbaijans, 2014).

A favourable ground was set up for the reforms in science after Azerbaijan restored state independence. The President of the Azerbaijan Republic Ilham Aliyev with his Decree dated January 4, 2003 broadened 
the range of activities of the Academy by conferring the Azerbaijan National Academy of Sciences a status of high state scientific organization that organizes and provides the development of science in the Azerbaijan Republic, carries out state policy in science and technology, coordinates and directs research activities of all the scientific institutions and higher schools in Azerbaijan and represents Azerbaijan in the field of scientific and technological activities in foreign countries.

The "State Programme on Development of Library-information spheres 2008-2013" (2008) and "State Programme on the implementation of the national strategy for the development of science in Azerbaijan Republic during 2009-2015" were ratified by the Order of the President of the Azerbaijan Republic Ilham Aliyev

As it was specified in the preamble of the "State Program on the development of library-information sphere in the Republic of Azerbaijan" (State Programme on the Development of the Library-Information Sphere, 2008), the events taking place in the early 90 s of the last century had negative impact on the activity of the libraries as well. Book publishing and supply system was completely paralyzed, their material-technical base was substantially weakened. All these factors caused the decay of the library sphere. Consequently, libraries had lost their real and potential reader, a lot of libraries were closed, majority of them couldn't meet the demands of the readers, a large number of staff was reduced. The number of copies in the general book stock of the libraries in the Republic has been reduced since 1990. The main reason of it was complete destruction of 9 Centralized Library Systems, 927 libraries in the issue of occupation of 20\% of the Republic by Armenian armed forces, non-provision of libraries with the fund for purchasing the new publications as well as removal of books losing their importance on the content and morally outdated.

As Azerbaijan, a number of capitalist countries suffered from financial difficulties in early 1990s as well. The sharp shortfall revenue from the Eastern countries on exchange has started since 1990. It was related to the change of political situation in those countries (Aybaniz Aliyeva-Kangarli, 2011).

Poland was the leader in this group of countries. Upon reorganization of Poland AS in 1991, the number of documents purchased from this organization had sharply decreased. Notwithstanding the fact that 980 copies of book and journal were obtained from Poland AS Distribution Center for Scientific Publications at the end of 1980 s, less than 50 copies were received in the beginning of 1990s. Table 1. shows increasement of international book exchange in that period. Table 2. shows numbers of libraries and books, as weel as, the number of books per 1000 population.

Table 1

Main indicators of international book exchange of Azerbaijan libraries

\begin{tabular}{|c|c|c|}
\hline Years & Sent & Received \\
\hline 1983 & 23490 & 28734 \\
\hline 1993 & 6570 & 18733 \\
\hline 2003 & 32193 & 44983 \\
\hline 2013 & 53922 & 51098 \\
\hline Total for 20 years & 116175 & 143548 \\
\hline
\end{tabular}


Main indicators of library activity in Azerbaijan

\begin{tabular}{|l|c|c|c|c|}
\hline & 1990 & 2000 & 2010 & 2013 \\
\hline Number of public libraries & 4605 & 4374 & 3947 & 3320 \\
\hline of which - library stock million copies & 45.3 & 38.7 & 36.1 & 33.5 \\
\hline per 1 000 population, copies & 6280 & 4867 & 4012 & 3581 \\
\hline & & & & \\
\hline Number of scientific libraries & 18 & 17 & 17 & 17 \\
\hline of which - library stock million copies & 5,2 & 7,3 & 8,7 & 9.4 \\
\hline per 1 000 population, copies & 720 & 918 & 966 & 1004 \\
\hline
\end{tabular}

\section{HISTORICAL REVIEW OF THE PROBLEMS OF THE PERIOD}

Restoration of the contracts for preventing the sharp shortfall of literature revenues on the international book exchange at the mentioned period and opportunities of searching for the new potential partners on the book exchange were observed.

The release of books especially, scientific publications had substantially decreased during 1990-1995. Delays in the release of academic journals led to the increase of the number of reclamations provided by the foreign partners and significantly retarded execution of orders and equivalent exchange process. The changes occurred in the material-technical base of scientific-research institutes of ANAS as well as import of advanced printing technologies to the country had caused the gradual increase in the volume of printed publications in the Republic as well as the number of scientific publications has started to increase since 1996. This process led to the relative increase of the level of literature export abroad.

The Central Scientific Library cooperating with 632 scientific organizations from 43 countries established cooperation relationships with 3 new partners - Beijing Institute of Natural Sciences, Iran National Library, Ayatollah al-Marashi-al-Najaf Public Library (Qom) in 1996. The library became the member of "Board of Directors of scientific libraries and information centers" established under the International Association of the Academy of Sciences (Reports of the Central Scientific Library of ANAS, 1990-2000s).

At the same year the ambassador of Federal Republic of Germany to our country visited the Central Scientific Library conducted discussion with the management of the library on the issues of the use of German literature and invited the library employees to Germany for familiarizing with the activity of libraries in Germany. The great scientific team from Japan visited the Library in 1996 as well.

"Eastern Literature" fund of the Library had been significantly extended in those years as well. Owing to the international exchange with Turkey, Iran, Egypt, Jordan, Kuwait and other Muslim countries, literature written in Eastern languages constituted 35\% of the foreign publications fund. The activities of the local and foreign scientists conducted in this field shouldn't be forgotten as well. Tariyel Vali from Washington, Nuraddin Garavi from Bonn, Ali Yavuz Akpinar from Istanbul and Ankara, Omar Ozjan and others were always sending new publications to the Library. Precious and rare publication donations of the late Ziya Bunyadov to the Library became a tradition (Aybaniz Aliyeva-Kangarli, 2007).

The search of the central Scientific Library in 1997 for the new partner on book-information exchange yielded benefit. Archaeological Museum in Germany concluded the exchange contract with National Parliamentary Library of Japan.

Presidium of Russia AS adopted the new decision for strengthening cooperation with Azerbaijan AS in 1997. According to the decision, Russia AS Natural Sciences Library started to send scientific journals of 
"Nauka" publication free of charge to the Central Scientific Library. The Central Scientific Library undertakes to pay postage expenses only. In fact, "Pushkin library" of Russia joined this project in 1999 as well.

Mr. Tureval from National Library of Paris, Professor Jay from Texas University visited Baku for getting acquainted with the Central Scientific Library in 1997.

The Central Scientific Library completed its work on the restoration of the international book exchange with the large libraries of CIS countries in 1998. The relations with all former Soviet countries excluding Armenia were re-established. The more extensive cooperation was established with Russia AS Natural Sciences Library, VINITI, Natural Sciences Library of Russia AS, the State General Scientific-Technical Library of Russia, V.I. Vernadsky National Library of Ukraine, the Central Scientific Library of Belarus AS named after Y.Kolas, the Central Scientific Library of Latvia AS and Georgia AS.

On December 29, 1998 "Law on Library" was adopted in Azerbaijan for the first time in the field of library and information activities (The Law on Library, 1998).

The law put out the attitude of Azerbaijan government towards international relations of libraries, reaffirmed the promotion of comprehensive integration into the global information space. In the article 33 of document called "International cooperation in the field of library science" it is said: "International cooperation in the field of library science is carried out on the basis of interstate agreements supported by the Republic of Azerbaijan. Libraries and public associations in the field of library science may cooperate with international library organizations, libraries of foreign countries and public associations in the field of public associations".

The years of 1999-2000 was remembered as traditional process automation in the history of Central Scientific Library. Creation of electronic library and electronic catalogues, provision of service to readers over the Internet, carrying out international correspondence primarily via the e-mail were launched.

During these years, the Central Scientific Library was in contact with 600 scientific and educational institutions, publishing houses of 65 countries. Libraries and universities of USA, Russian, France, Great Britain, Canada, Germany, Italy, Turkey, Sweden, Japan and Austria were the most active partners of the library. During the years of 1990-2000, the Library carried out book and magazine exchange of 50 thousand copies with these or those partners.

In that period, 450 thousand out of 600 thousand periodicals fund of the Library were foreign scientific journals. In 2000, 4 thousand reader addressed to 20 thousand foreign academic journals. One point should be particularly highlighted that, if the readers in the 90 s were mainly interested in magazines on exact sciences, from the year of 2000 , the interest increased in foreign publications on economy, law, history, international relations and other social and political sciences. This is to be explained by the expansion of economic, political, scientific and cultural relations of Azerbaijan Republic with foreign countries.

In 2001, the Library became a member of several international organizations such as Assembly of Eurasian Libraries, Association of libraries of Turkic speaking States, Transcaucasian Information Specialists Association. In the same year, the relations were established with Hannover University Library of Germany and Geological Society of Germany, intensive books and information exchange was started. American Professor Robert Heyes who came to Baku in 2001 at the invitation of Central Scientific Library, organized a workshop called "Automation of library and information services: analysis and design" and a number of librarian of the Republic were awarded certificates. Besides, in the same year, the Russian Book Chamber representatives and Director of IFLA's "Protection and recovery" program on Eastern Europe and the CIS G.Kislovskaya visited the Central Scientific Library at different times and arranged a conference called "Library, archive and museum conservation" and a workshop called "Restoration Experience" with the participation of leading libraries. According to the workshop results, the Central Scientific Library's collabo- 
rator on conservation A . Rasulov was selected as a winner and successfully represented the Library in the international workshop called "Restoration work" that organized jointly by Russia and Austria in Moscow.

The 2001st year was marked in the international relations of Central Scientific Library with the fact that, since that time the academic journals of more than 4 thousand which were published around the world , have suspended their publication in paper version and began to broadcasting through the scientific database of USA called EBSCO over the internet.

As there were magazines obtained by the Central Scientific Library through the international book exchange in other words at no cost, this process affected negatively to completing of foreign literature.

Continuation of this process in subsequent years was remembered with the changes made by the Central Scientific Library to the acquisition policy and the Library began to make a statement before the management of Academy of Sciences with the demand of increasing funds allocated for paid acquisition. Otherwise, it was not possible to obtain scientific literature which the readers were interested in. Although the issue was soon resolved, funding shortfall also manifests itself today. All these are understandable against the background of extension in information collections, increase of interest and demand in foreign publications.

In 2002, Professor of Anthropology from Pennsylvania State of USA, Employee of Los Angeles City Library, California State, orientalist scholar, bibliographer, president of California Interlibrary Coordination Centre David Hirsh, Employee of Martin Luther University in Germany doctor Adam Folker visited the Library.

As getting a part of education in Marc Bloch University located in Strasbourg city of France, one of the authors (Babakhanova) since the end of 90s, has carried out certain works for the establishment of relations between Azerbaijan and France in the sphere of library science, investigated the possibility of cooperation with the Central Scientific Library by visiting the libraries in France and made the publications as a gift regarding those libraries, history and literature of Azerbaijan many times. After finishing his studies he began to closely cooperate with the Embassy of France in our country and in 2002, achieved to establish in Central Scientific Library “Azerbaijan France scientific-cultural relations” department led by him.

\section{PRESENT SITUATION}

Today, there are about 9000 libraries in Azerbaijan. All of them has an international books fund (Abuzar A. Khalafov et al, 2012). But, 24 of them have a very robust international relations. Despite the fact that this relationship began to build in the 1950-1960 years, the Azerbaijani libraries feels independent activities in this area, only after the destruction of the USSR. In the Soviet Union, many Azerbaijani libraries have foreign literature funds. Funds for its purchase from the budget allocated and distributed centrally. The country aims to have as many foreign publications in the libraries. But the international exchange process is strictly regulated and controlled.

After the fall of the Soviet Union, almost all newly formed Sovereign Republics' libraries were faced with international cooperation problems during the period of 1991-1997. The break established professional relationships and interactions, witnessed the decay of publishing and book supply, a rapid rise in prices, and increased shipping costs and customs duties. All of these problems, have dramatically reduced the value of library collections, and created a risk of cultural and informational isolation from the community. But, actively opposing the process of cultural disintegration, the libraries survived and managed to ensure the stability of their life, to preserve their influence in the human society (J.A.Jafarov, 2012).

Since 1998, the Azerbaijani libraries began to restore the old international relations. International Book Exchange began evolve very quickly but not systematic. The process continued before the beginning 
of 2000. In this sense, it can be deemed that the 1991-2000s, is a period of accumulation of new skills in the international sphere by Azerbaijani libraries.

Since 2000, Azerbaijan's library works closely with international organizations such as IFLA, IBER, CENL. Libraries are participating in all the conferences of these organizations (Reports of the Azerbaijan National Library, 1995-2000s).

Also, our libraries are active participants in these international book festival held annually in Frankfurt, London, Moscow and so on. There libraries receive extensive experience in international relations. In addition, in these events to discuss details of the new partnership is very high.

According to the 2014 statistics, Azerbaijani libraries cooperate with 980 scientific organizations, libraries and universities of 87 countries. In 2013-2014, in general, Azerbaijani libraries have acquired 90,532 copies of foreign literature. In return, 84,054 books and magazines have been sent to foreign partners. Different types of publications were sent to and get from abroad during independence years (1990-2013). These publications consist of books, scientific journals, e-publications and others. Diagrammes 1 and 2 are used for the explaining the numbers of publications get from and sent to abroad.

$\llbracket$ Books $(61 \%) \quad \square$ Journals $(23 \%) \quad \llbracket \mathrm{CD}(10 \%) \quad \llbracket$ Other $(6 \%)$

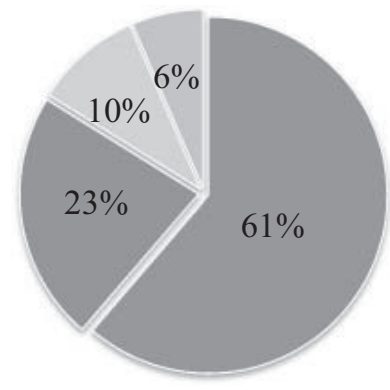

Diagramme 1. Types of scientific publications sent abroad from Azerbaijan (1990-2013)

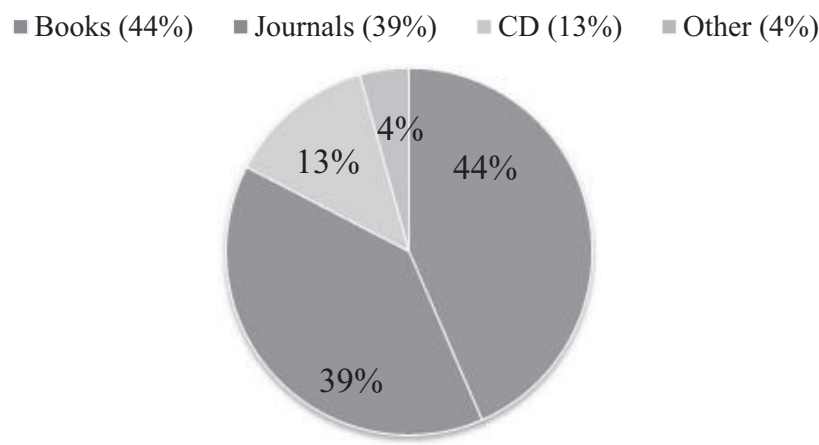

Diagram 2. Types of scientific publications received from other countries (1990-2013) 
It should be noted that, the Azerbaijani libraries have long engaged in international book exchange, nowadays changed their approach to the process, trying to make it more effective and useful for themselves. For the exchange of libraries often use literature printed by them or organizations to which they belong. Thus, libraries of universities and research organizations are widely used for the exchange the monographs, academic journals, bibliographic materials and other custom publications. For the libraries, it's cheap, and interchange of these publications raises the level of international exchange, generally.

The basic principle of conducting of international exchange is a voluntary agreement on the exchange on mutually beneficial terms (Abuzar A. Khalafov, 2003). Libraries exchange lists of literature offered for exchange. From this list, each library selects their favorite publications on the exchange which will subsequently signed a contract.

In recent years, more attention is drawn to the electronic publications and electronic access to documents, which greatly facilitates the process of obtaining information. Electronic publications partially replaces the printed materials. Azerbaijani libraries try to receive/send more electronic publications instead of print editions, but it is not always possible with exchange.

Today, international book exchange in the majority expressed in the exchange of publications, but in the future, electronic documents' exchange will develop. Libraries are already creating their own electronic information products that can be exchanged. As an example case bibliographic databases.

\section{CONCLUSION}

Since Azerbaijan regained independence, international scientific and cultural ties have become one of the important instruments of the new foreign policy. The main aims of the policy have been to foster relations based on mutual understanding and trust with other countries, work with them on the basis of mutual benefit and equal rights, and to give to the world a clear, objective picture of the Republic of Azerbaijan.

The main directions of international scientific and cultural policy are the development of international cooperation by promoting multilateral collaboration in the framework of international organisations; strengthening of bilateral relations with leading European, American, Asian and African states; supporting the Azerbaijan national cultural centres functioning abroad are the main directions of international cultural cooperation (Country profile, 2014).

Summarizing the research it can be concluded that the years of 1990-2000, was quite challenging and productive period in the history of Azerbaijani libraries, including Central Scientific Library. At that time line the Azerbaijani libraries renewed the relations with scientific and educational institutions operating in different countries of the world and created favourable conditions for $f$ international cooperation of new period. Since 1990s, the strengthening relations with international organizations in the field of library science and continuing today are the result of proper activities established by Azerbaijani libraries at the end of the XX century and at the beginning of the XXI century.

\section{REFERENCES:}

Abuzar A. Khalafov, Aybaniz Aliyeva-Kangarli, Javid A. Jafarov. (2012) Biblioteche in Azerbaigian: l'attuale situazione dei processi di automazione e di catalogazione, "Bibliotime", Bologna, Italy, anno XV, numero 2 luglio, 71-77 pp. Abuzar A. Khalafov. (2003) The introduction to Library science: Textbooks: B.: BUP, 314 p.

Aybaniz Aliyeva-Kangarli. (2007) Information maintenance of a science in the modern Azerbaijan and libraries Baku, ANAS, 393 p. 
Aybaniz Aliyeva-Kangarli. (2011) National and spiritual values: creators and succesors, Baku, Progress, 582 p.

Berezka A. (2010) Financing of the Scientific and Research Activity of a University in the Perspective of the Changeable Criteria of a Knowledge Based Economy and International Aspects, Economics and Sociology, Vol. 3, No 2, 2010, pp. 128-134.

Javid A. Jafarov. (2012) Azerbaijani libraries in the digital age: future prospects and concerns. Int. J. of Acad. Res., Part B; V.4. No.4, 83-85.

Láb, F., Němcová Tejkalová, A. (2014). Journalist Education and Truth in the Digital Age: Why We Need Critical Digital Literacy. In: Stocchetti, M. (ed.). Media and Education in the Digital Age: Concepts, Assessments, Subversions. Frankfurt am Main: Peter Lang, pp. 105-116. ISBN 978-3-653-04437-9

Reports of the Azerbaijan National Library (1995-2000 years).

Reports of the Central Scientific Library of ANAS (1990-2000 years).

State Programme on the Development of the Library-Information Sphere in the Republic of Azerbaijan 20082013 (2008). Ratified by order $\otimes 3072$ of the President of the Republic of Azerbaijan dated on 6 October 2008.

The Law on Library of the Republic of Azerbaijan. Dated from December 29, 1998.

Country profile. Azerbaijan/ Council of Europe/ERICarts: "Compendium of Cultural Policies and Trends in Europe", $15^{\text {th }}$ edition 2014.

www.azerbaijans.com 